\title{
Veden estetiikka Hollywoodin ja Mosfilmin elokuvakerronnassa
}

\author{
Pentti Stranius
}

Elokuva on tekniikaltaan pelkkä valokuvien virta, johon on lisätty ääniraita. 24 kuvan sekuntivauhdilla pauhaava nauha, joki. Kaikki virtaa - välillä myös pimeässä salissa istuvien silmistä valuvat kyyneleet. 100 vuotta sitten elokuvateatterin laajakangas oli katsojan kokemana kuin lainehtiva meri, jonka II maailmansodan jälkeen yleistynyt televisio typisti pieneksi puroksi. 2000-luvulla, interaktiivisen virtuaalitodellisuuden tai kyberavaruuden aikakaudella, elävien kuvien virtaan voi astua myös mukaan ja ajelehtia siinä toivomaansa suuntaan - vaikka Niagaran putouksille tai vesisänkyyn yhdessä Marilyn Monroen kanssa.

Kompetenssini ei riitä tämän kiihtyvällä nopeudella teknistyvän kuvavirran tai virtuaalitodellisuuksien erittelyyn. Tuon seuraavassa esiin pari huomiota perinteisen teatterielokuvan vesi-estetiikasta Amerikan Hollywoodissa ja Neuvostoliiton Hollywoodiksi mainituilla Mosfilmin studioilla.

Eri maiden elokuvataiteessa esiintyy aina samoja elävästä elämästä tai muista ulottuvuuksista napattuja draaman aineksia. Kulissit sen sijaan vaihtelevat kansallisten kulttuurien mukaan. Tähän perustuu myös ns. sarjaformaattien vyörytys globaalin television aikakaudella: samat hyviksi havaitut formaatit pyörivät joka puolella maapalloa, vain pienin periferisin lisämaustein höystettyinä. Katsojat itkevät ja nauravat, pitkästyvät tai innostuvat samoissa kohdissa, samojen ärsykkeiden yllyttäminä. Jos ajatellaan vettä elokuvallisen draaman kulissina, esimerkiksi amerikkalaisen ja venäläisen elokuvakerronnan välillä on melkoisia eroja. Erilaisilla meren ja veden kuvilla, vesi-elementin käytöllä saattaa olla jotakin tekemistä myös imperiumien tai kansakuntien rakentamisenkin kanssa(?).

Amerikkalainen meri-imperiumi on ottanut valtameret ja niiden takaiset mantereet haltuun myös elokuvallisin keinoin - usein merelliset uhkakuvat kesyttäen ja myyttejäkin synnyttäen. Hollywood-estetiikassa vallitsevat toistuvat titanic-katastrofit, tulvat, hirmumyrskyt, normandian maihinnousut, meressä vaanivat tappajahait ja vedestä nousevat erilaiset lochness-hirviöt tai saarilla asustelevat dinosaurukset ja kingkongit. Meren ranta, beach, on taas se lainelautailun ja tissiviihteen (tittytainment), siis rauhan ja rakkauden tyyssija.

Kun Francis Ford Coppolan ohjaaman Ilmestyskirja.Nyt-elokuvan sankarit esimerkiksi rantautuvat Vietnamiin, heitä kiinnostaa taistelun melskeessä myös surfailu Mekong-joen suistossa - 
siis aaltojen korkeus, kalifornialainen tuttuus. Partiomatka jokea pitkin syvälle viidakkoon onkin jo sitten kammottavampi koettelemus kohti tuntematonta - suoraan pimeyden sydämeen, jossa odottaa sodan märkä ja verinen helvetti, lopullinen hulluus vetisesä viidakossa: Marlon Brandon hikisessä hahmossa.

Venäläisen elokuvallisen, ns. euraasialaisen aroimperiumin rakentamiseen on kulunut ja kuulunut paljon niukemmin merellistä vettä. Tälläkin imperiumilla on kaikille merille muuten kyllä ollut kova hinku. Pääosassa - esteinä ja uhkina - ovat siperian taigat, raivattavat arot, kaukasuksen vuoret ja merten sijalla maata halkovat valtavat joet, elokuvien nimissäkin: Hiljaa virtaa Don ja Volga, Volga. Esimerkiksi neuvostokauden yltiöisänmaallisissa sotaelokuvissa soiden, jokien, arojen ja muiden luonnonesteiden ylitykset saavat usein pitkästyttävän pikkutarkan kuvauksen.

Voisi sentään olettaa, että eisensteiniläinen klassikko, Panssarilaiva Potemkin, ylvästelisi nimenomaan vesimaisemin. Elokuvallinen kliimaksi saavutetaan kuitenkin Odessan porraskohtauksella - eihän Musta meri mikään oikea meri olekaan! Eisensteiniläisen montaasin arkkivihollinen, Andrei Tarkovski, sijoitti elokuvallisen avaruusmerensä (Solaris) kauas kosmokseen. Jokia ja suoalueita sen sijaan ylitetään jo esikoisohajuksessa (Ei paluuta).

Elokuvaa kaikkialla vainoava sensuuri on häirinnyt Hollywood-estetiikkaa veden suhteen kohtalaisen vähän. Tappajahait ja hirmuliskot ovat saaneet pelotella katsojia kaikessa rauhassa. Myös Alfred Hitchcockin Psykon suihkukohtauksen alaston, näkymätön ja raaka väkivalta meni läpi jo aivan 1960-luvun alussa. Liian märät seksikohtaukset - vedessä, rannalla, suihkussa, ammeessa - sitävastoin on usein karsittu pois.

Sekä Hollywoodissa, Suomi-Filmillä että Mosfilmillä kamera on usein karannut taivaalle tai merelle, kun elokuvan sankaripari on ryhtynyt lemmenpuuhissaan tositoimiin. Niin sanotun "täyttymyksen kokeminen" vertautuu vesimaisemiin, aaltojen loiskeeseen, kosken kuohuun, sateeseen. Toki muutkin järisyttävät luonnonilmiöt käyvät, kunhan vievät katsojan mukaan sekä kuviteltuun kosteaan syliin että aktin rytmiin. Tämä on paitsi erittäin yleinen sensuurin kiertämismuoto myös hienoviritteinen taiteellinen ilmaus "täyttymykselle" vähemmän paljasta pintaa sallivissa kulttuureissa.

Neuvostoliitossa, missä ns. hyllytysten estetiikka sai kaikenkattavan valtiollisen sensuurin mittasuhteet, myös veden kuvaaminen pistettiin toisinaan kontrolliin. Vielä 70-luvullakin. Aleksandr Sokurovin Yksinäinen ihmisääni oli keskeisissä Potudanjoki-kuvissaan liian estetisoiva. Joen virtaamiskuvat olivat "formalistista tekotaidetta" eivätkä sopineet sosialistisen realismin raameihin. Ennenkuulumatonta röyhkeyttä oli sekin, että filmin kansalaissodasta palaileva sankari kuvattiin impotentiksi, joka hautoi mielessään jokeen hukuttautumista. Toisaalta Yksinäisen ihmisäänen sensurointiin saattoi olla yksinkertaisempiakin syitä. Elokuvan käsikirjoitushan perustui kielletyn, talonmiehentöitä paiskineen kirjailijan, Andrei Platonovin Potudanjoki-novelliin.

Andrei Smirnovin ohjaama Syksy-elokuva sisälsi puolestaan paitsi liikaa vesisadetta, myös kolmiodraaman ja sänky-erotiikkaakin sateen ropistessa ulkona. Sensorien pyynnöstä elokuvan koko keston vallitseva "ankea" sadesää rikottiin lisäämällä Syksyyn 50 metrin filminpätkä "optimistista" auringonpaistetta. Tämä on ehkä ainut kerta neuvostoelokuvan historiassa kun Mosfilmin punakynäsensorit onnistuivat parantelemaan jopa neuvostoelokuvan säätilaa. *)

Stalinin kipsipään pudottaminen vahingossa akvaarioon saattoi myös koitua kohtalokkaaksi. Tällainen huolimattomuus lopetti erään taiteilijauran 40-luvun Gruusiassa, koska 
vertauskuvallinenkin Isä Aurinkoisen hukuttaminen julkisissa juhlissa oli ilman muuta vertaansa vailla oleva rikos. Poika, syyllinen, kehitteli episodista sittemmin kokonaisen elokuvan (Uimari). Sekin ehdittiin kieltää vielä 80-luvun alussa. Mutta pian ideologinen sensuuri Venäjällä sai väistyä, jolloin Hollywood-estetiikka sarjaformaatteineen (Kauniit ja rohkeat, Miami Beach, Santa Barbara) aloitti pikaisesti hyökyaaltomaisen Normandian maihinnousun marxismileninismistä autioituneelle Euraasia-vyöhykkeelle.

Lopuksi pseudotieteellinen johtopäätös meren puuttumisesta, veden sensuroinnista neuvostoelokuvassa: meriestetiikan vähäisyys Mosfilmillä voisi olla osoitus Venäjän ikuisesta euraasiailaisesta traumasta. Kun imperiumilla oli jatkuvasti toivottomia vaikeuksia päästä kattavasti kaikille merille ja vesille saakka, piti tuo hankala elementti minimoida - joko tiedostamatta itsesensuurilla tai valtiollisin sensuuritoimin? - myös elokuvasta, kansakunnan kätketystä muistista...

\section{Viitteet}

*) En ole kuitenkaan varma mitä on tapahtunut muilla studioilla. Säätilaa on saatettu käpälöidä enemmänkin. Esim. myöhäissyksyinen leningradilais-pietarilainen tuulinen märkyys on usein iholla koettuna niin läpitunkevan vetinen, että sitä soisi mielellään paranneltavan edes elokuvayleisölle. Neva-joen yllä ei marraskuussa näe toisinaan yhtään ns. selvää pilveä, vain harmaan yhtenäisen tihkuvan maton... Pietarissa 5 vuotta asuneena en pane pahakseni, vaikka Lenfilmin sensorit olisivatkin onnistuneesti muuttaneet useammankin kaupungissa kuvatun fiktion tai dokumentin sääoloja neuvostokansalaisen helpommin kestettäviksi!

Pentti Stranius, FL

Karjalan tutkimuslaitos

pentti.stranius@joensuu.fi 